\title{
Methane production by in vitro ruminal fermentation of feed ingredients
}

\section{Produção de metano pela fermentação ruminal in vitro de ingredientes}

\author{
Antonio Carlos Homem Junior ${ }^{1}$; Jane Maria Bertocco Ezequiel'2; \\ Vanessa Ruiz Fávaro ${ }^{3}$; Marco Tulio Costa Almeida ${ }^{1}$; Josimari Regina Paschoaloto ${ }^{1 *}$; \\ André Pastori D’Áurea ${ }^{4}$; Vanessa Barbosa de Carvalho ${ }^{5}$; \\ Bruno Faleiros Nocera ${ }^{6}$ Leonardo Fernandes Cremasco ${ }^{6}$
}

\begin{abstract}
This study investigates the methane and carbon dioxide gas production, dry matter degradation, and final $\mathrm{pH}$ values obtained during the in vitro incubation of corn grain, soybean hulls, citrus pulp, corn silage, and crude glycerin. Experiments were performed using a randomized block design with four incubation periods. Each period featured four replicates per ingredient and four blanks, totaling 16 repetitions per ingredient. The lowest total amount of produced gas $\left(37.96 \mathrm{~mL}_{\text {incubated DM }}{ }^{-1}\right)$ and the lowest final $\mathrm{pH}$ value $(4.95)$ were obtained for crude glycerin $(P<0.05)$, which, however, exhibited the highest $(P<0.05)$ DM degradation. Citrus pulp produced the largest amount $(P<0.05)$ of $\mathrm{CH}_{4}$ per gram of incubated DM $\left(13.56 \mathrm{~mL} \mathrm{~g}^{-1}\right)$. However, when methane production was expressed per gram of degraded feed, the ingredients with lower degradation values, such as soybean hulls and corn silage, produced more $\mathrm{CH}_{4}$ per gram of degraded DM. Citrus pulp and corn grain produced more $(P<0.05)$ $\mathrm{CO}_{2}$ per gram of incubated DM. However, per gram of degraded food, citrus pulp produced the largest amount of $\mathrm{CO}_{2}(P<0.05)$. Crude glycerin and corn grain produced less methane (per gram of degraded feed) than citrus pulp, soybean hulls, and corn silage. Differentiation of ingredients based on their methane production ability is important to express methane production per unit degraded food mass.

Key words: Carbon dioxide. Corn. Crude glycerin. Dry matter degradation. pH.
\end{abstract}

\section{Resumo}

Objetivou-se estudar os ingredientes milho, casca de soja, polpa cítrica, silagem de milho e glicerina bruta, avaliando a produção dos gases metano e carbônico, a degradação da matéria seca e o pH final da incubação in vitro. Utilizou-se o delineamento em blocos casualizados, com quatro períodos de incubações, em que cada período teve 4 repetições por ingrediente e 4 brancos, totalizando 16 repetições por ingrediente. A glicerina bruta apresentou menor produção total de gases $\left(37,96 \mathrm{~mL} \mathrm{~g}^{-1}\right.$ de MS incubada), menor valor de $\mathrm{pH}$ final $(4,95)$ aliado à maior degradação da MS. A polpa cítrica

1 Discentes, Curso de Doutorado do Programa de Pós-Graduação em Zootecnia, Universidade Estadual Paulista, Faculdade de Ciências Agrárias e Veterinárias, FCAV/UNESP, Jaboticabal, SP, Brasil. E-mail: achomemj@hotmail.com; jpaschoaloto@ yahoo.com.br; marcotulio695@yahoo.com.br;

2 Prof ${ }^{\mathrm{a}}$ Dr$^{\mathrm{a}}$, Departamento de Zootecnia da Universidade Estadual Paulista, Faculdade de Ciências Agrárias e Veterinárias FCAV/ UNESP, Jaboticabal, SP, Brasil. E-mail: janembe_fcav@yahoo.com.br

3 Empresa de Pesquisa Agropecuária e Extensão Rural de Santa Catarina, Estação Experimental de Lages, Lages, SC, Brazil. E-mail: vanessa favaro@yahoo.com.br

4 Premix ${ }^{\circledR}$. E-mail: andredaurea@ig.com.br

5 InVivo Nutrição e Saúde Animal@. E-mail: vancarvalho_zoo@hotmail.com

6 Discentes, Curso de Graduação em Zootecnia, Universidade Estadual Paulista, Faculdade de Ciências Agrárias e Veterinárias, FCAV/UNESP, Jaboticabal, SP, Brasil. E-mail: bruno_faleirosn@hotmail.com; leonardocremasco@yahoo.com.br

* Author for correspondence 
foi o ingrediente com maior $(\mathrm{P}<0,05)$ produção de $\mathrm{CH}_{4} \mathrm{~g}^{-1} \mathrm{MS}$ incubada $\left(13,56 \mathrm{~mL} \mathrm{~g}^{-1}\right)$, no entanto, ao expressar a produção de metano por unidade de alimento degradado, os ingredientes com menores degradações, como a casca de soja, a polpa cítrica e a silagem de milho, produziram mais $\mathrm{CH}_{4} \mathrm{~g}^{-1} \mathrm{MS}$ degradada. A polpa cítrica e o milho apresentaram maiores $(\mathrm{P}<0,05)$ produções de $\mathrm{CO}_{2} \mathrm{~g}^{-1} \mathrm{MS}$ incubada, porém, por unidade de alimento degradado, a polpa cítrica se destacou com maior produção $(\mathrm{P}<0,05)$. $\mathrm{O}$ milho e a glicerina bruta produzem menos metano por unidade de alimento degradado em relação à polpa cítrica, casca de soja e a silagem de milho Para diferenciar a produção de metano dos ingredientes é importante expressar os valores por unidade de alimento degradado.

Palavras-chave: Degradação da MS. Dióxido de carbono. Glicerina bruta. Milho. pH.

\section{Introduction}

Ruminal degradation of feeds produces shortchain fatty acids (in particular, acetic, propionic, and butyric acids) as well as $\mathrm{CO}_{2}$ and $\mathrm{H}_{2}$. These two gases are converted into $\mathrm{CH}_{4}$ by methanogenic bacteria. It is estimated that $6-18 \%$ of the gross energy intake is wasted as ruminal methane, which is an aggravating factor for global warming, with $23 \%$ of the global methane originating from domestic ruminant animals (WUEBBLES; HAYHOE, 2002; PEDREIRA; PRIMAVESI, 2006; TODD et al., 2011).

Several factors influence ruminal methane production, e.g., dry matter consumption, lipid supply, non-fiber carbohydrate diet, ingredient digestibility, and forage/concentrate ratios (ELLIS et al., 2007; TAMBURINI et al., 2010; GRAINGER; BEAUCHEMIN, 2011). When ruminants receive a large amount of forage, a higher amount of methane is produced from digested ingredients, while large amounts of grain decrease methane production. This behavior is directly related to the proportion of acetic, propionic, and butyric acids formed. For example, the higher proportion of propionate formed during ruminal fermentation enables $\mathrm{H}_{2}$ capture without $\mathrm{CO}_{2}$ formation, which does not favor the methanogenic bacteria. On the other hand, the production of acetate and butyrate liberates $\mathrm{CO}_{2}$ and $\mathrm{H}_{2}$, which are $\mathrm{CH}_{4}$ precursors, into the ruminal environment(VAN SOEST, 1994; JANSSEN, 2010). Ingredients with high non-fibrous carbohydrate content may increase the proportion of propionic acid produced, thus decreasing methane production (VAN NEVEL; DEMEYER, 1995; MITSUMORI; SUN, 2008).
Only few studies have evaluated the above mentioned methane production by ruminal fermentation, which is greatly important to elaborate diets resulting in lesser methane production. Therefore, this study evaluated the production of $\mathrm{CH}_{4}$ and $\mathrm{CO}_{2}$ from some energy-rich ingredients used in ruminant feeds, employing an in vitro gas production technique.

\section{Material and Methods}

Three heads of cattle with a permanent rumen fistula were used in the experiment, being fed twice a day with a diet based on the studied ingredient, using $50 \%$ concentrate and $50 \%$ corn silage as forage.

\section{In vitro incubation of ingredients}

Prior to feeding, the rumen content was collected and filtered in a nylon bag $(100 \mu \mathrm{m})$, and the ruminal fluid was diluted with an artificial saliva buffer in a $1 / 2$ ratio. The saliva buffer was composed of buffer solution $\mathrm{A}\left(\mathrm{KH}_{2} \mathrm{PO}_{4}=10.0 ; \mathrm{MgSO}_{4} \cdot 7 \mathrm{H}_{2} \mathrm{O}=0.5\right.$; $\mathrm{NaCl}=0.5 ; \mathrm{CaCl}_{2} \cdot 2 \mathrm{H}_{2} \mathrm{O}=0.1$, and urea $=0.5$, all numbers in $\left.\mathrm{g} \mathrm{L}^{-1}\right)$ and buffer solution $\mathrm{B}\left(\mathrm{Na}_{2} \mathrm{CO}_{3}\right.$ $=15.0$ and $\mathrm{Na}_{2} \mathrm{~S} \cdot 9 \mathrm{H}_{2} \mathrm{O}=1.0$, all numbers in $\left.\mathrm{g} \mathrm{L}^{-1}\right)$ in a 5:1 ratio (ANKOM Technology Method 3). Over a period of $24 \mathrm{~h}$, four in vitro incubations of the energy-rich ingredients, namely corn grain, soy hulls, citrus pulp, corn silage, and crude glycerin, were performed. Crude glycerin was obtained from soy oil and contained around $\left(\mathrm{g} \mathrm{L}^{-1}\right)$ glycerol $=830.0$ glycerol, water $=109.9$, salts $=60.0$ and methanol $=$ 0.1(Caramuru Alimentos LTDA $\left.{ }^{\circledR}\right)$. 
For the incubation process, except for the case of glycerin, the ingredients were ground to 1-mm particles in a Wiley-type mill, weighed, and placed into fermenters (250-mL Erlenmeyer flasks) in the proportion of $1.25 \mathrm{~g} \mathrm{DM}$ per $100 \mathrm{~mL}$ of buffer ruminal fluid. For all incubation periods, the five ingredients were evaluated using four replications and four blank solutions (buffer ruminal fluid only).

The ingredients were incubated in a water bath under stirring at $39^{\circ} \mathrm{C}$ in the dark, and the produced gases were collected by a capillary system and stored in a plastic container, where the total amount of produced gas was read after $24 \mathrm{~h}$ of incubation.

Methane analysis, in vitro DM degradation, and $p H$

Gas samples were injected into a gas chromatograph (Trace GC Ultra, Thermo Scientific) equipped with a methanator and a flame ionization detector, using argon as a carrier gas at a flow rate of $25 \mathrm{~mL} \mathrm{~min}{ }^{-1}$ and an oven temperature of $70{ }^{\circ} \mathrm{C}$. Calibration was performed using a standard gas mixture of $\mathrm{CH}_{4}$ and $\mathrm{CO}_{2}$, and the peak areas were integrated using Chromquest 5.0 software.
After incubation, the final $\mathrm{pH}$ values were determined by a Digimed DM-20 pH meter, and the non-degradable incubation residue was obtained by centrifugation at $1,000 \mathrm{~g}$ for $3 \mathrm{~min}$ at room temperature (Excelsa ${ }^{@}$ II 206 MP). The sediment obtained by centrifugation was dried in a forced air flow oven (Fanem 330) at $55{ }^{\circ} \mathrm{C}$. The in vitro ruminal DM degradation was calculated as follows:

$$
\text { DMdeg }=\frac{\text { DMinc }-(\text { DMres }+ \text { DMbl })}{\text { DMinc }}
$$

where DMdeg stands for dry matter degradation, DMinc for incubated dry matter, DMres for residual dry matter, and DMbl for blank residual dry matter.

The ingredients (Table 1) were analyzed according to their dry matter, crude protein, ethereal extract (AOAC, 1984), neutral detergent fiber (using $\alpha$-amylase), and sequential acid detergent fiber contents (VAN SOEST et al., 1991). The starch content was determined according to the method of Hendrix (1993).

Table 1. Chemical composition of the ingredients used for in vitro fermentation.

\begin{tabular}{lcccccc}
\hline \multirow{2}{*}{ Ingredient } & \multirow{2}{*}{$\mathrm{DM}\left(\mathrm{g} \mathrm{kg}^{-1}\right)$} & $\mathrm{CP}$ & $\mathrm{EE}$ & $\mathrm{NDF}$ & $\mathrm{ADF}$ & Starch \\
\cline { 3 - 7 } & 908 & 84 & 30 & 547 & 301 & 233 \\
Corn silage & 916 & 113 & 14 & 740 & 579 & 23 \\
Soy hulls & 883 & 74 & 22 & 238 & 180 & 6 \\
Citrus pulp & 919 & 96 & 44 & 105 & 28 & 645 \\
Corn grain & 890 & - & - & - & - & - \\
Crude glycerin & &
\end{tabular}

DM: dry matter; CP: crude protein; EE: ether extract; NDF: neutral detergent fiber; ADF: acid detergent fiber.

\section{Statistical analyses}

Data were analyzed using a randomized block design with four blocks, five treatments, and four replications. Treatment was used as a fixed effect, with period and treatment $\times$ period used as random effects in the statistical model utilizing the mixed procedure. The means were compared using the least square method.

\section{Results and Discussion}

The greatest gas production by incubated dry matter was observed for citrus pulp and corn grain, followed by soy hulls and corn silage, with the lowest value observed for crude glycerin (Figure 1). 
Figure 1. Total gas production (in $\mathrm{mL} \mathrm{g}^{-1}$ ) of incubated DM (grey) and degraded DM (black) in energy-rich ingredients.

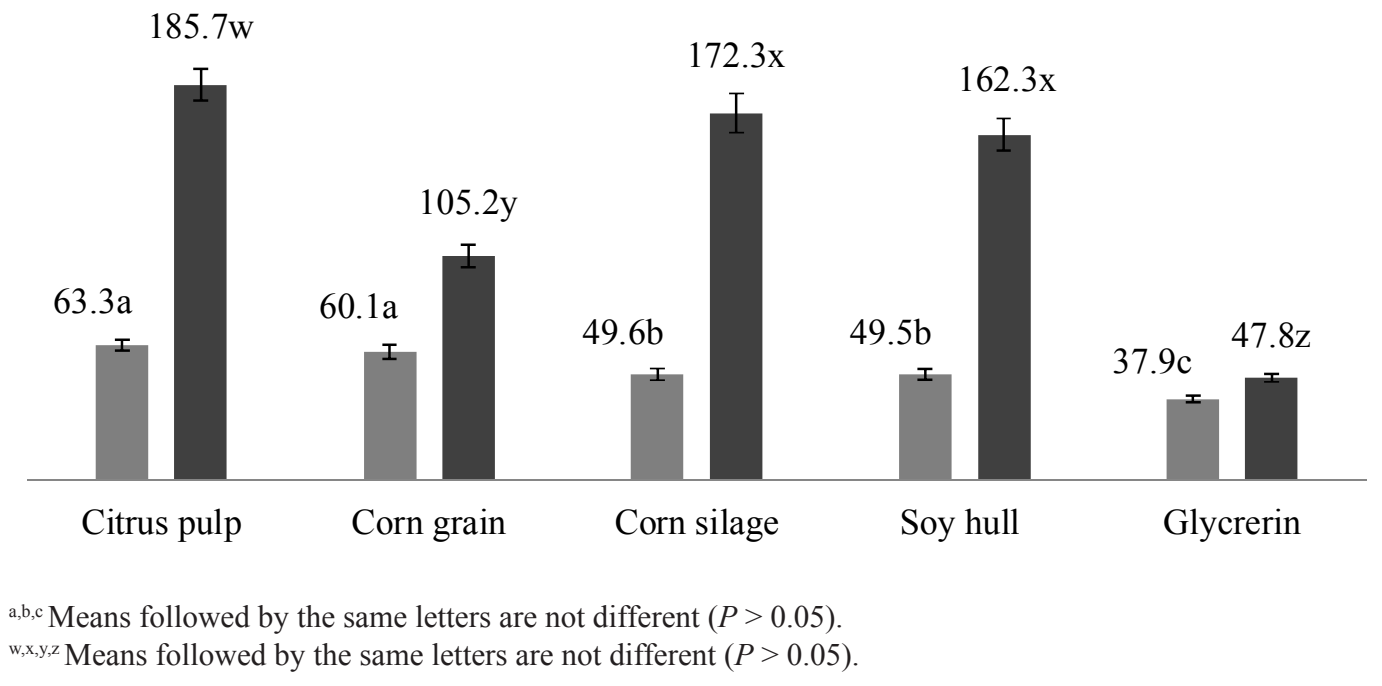

Citrus pulp is rich in pectin, which exhibits a fermentative behavior similar to that of non-fibrous carbohydrates, despite being a fibrous carbohydrate itself. This may lead to enhanced gas production, as in the case of corn grain. The elevated neutral detergent fiber NDF concentration in corn silage and soy hulls might explain their lower total gas production, because contrary to non-fibrous carbohydrates, NDF directly reduces in vitro gas production in $24 \mathrm{~h}$ (PIRONDINI et al., 2012).

Glycerin showed fast fermentation during the first $12 \mathrm{~h}$ of incubation, which might justify its low total gas production after $24 \mathrm{~h}$. According to Donkin (2008), around 50 to $70 \%$ of glycerin is consumed in the rumen within $4 \mathrm{~h}$. This leads to a slower gas production by glycerol when evaluated over a long time period (FERRARO et al., 2009).

The incubated glycerol, alone or mixed with corn/alfalfa, reduces in-vitro gas production in 24 h (FERRARO et al., 2009; LEE et al., 2011). The ruminal fermentation of glycerin can result in a higher propionate content, which is reflected in the total gas production (BLUMMEL et al., 1997; CONE, 1998; LEE et al., 2011).

When the total gas production was expressed per gram of degraded dry matter, corn produced less gas than citrus pulp (Figure 1), reflecting the dominant ruminal dry matter degradation of the former. Corn and glycerin exhibited the lowest total gas productions expressed in relation to degradation, showing better efficiency of ruminal fermentation. The lower gas production is probably correlated with a larger extent of microbial growth (RYMER et al., 1999).

Soy hulls exhibited the highest final $\mathrm{pH}$ value, followed by corn silage, citrus pulp, corn grain, and crude glycerin, in descending order $(P<0.05)$. A negative correlation $\left(R^{2}=-0.76, P<0.0001\right)$ was observed between the final $\mathrm{pH}$ and ruminal DM degradation of ingredients. Furthermore, high ruminal degradation is possibly accompanied by increased acid production. However, the amounts of acids (lactic, acetic, propionic, and butyric) and their proportions are not the only factors determining the final $\mathrm{pH}$.

Ingredients rich in fibrous carbohydrates, e.g., citrus pulp, soy hulls, and corn silage, exhibited minor DM degradation in comparison to corn and glycerin. Due to the dominant ruminal degradation of glycerin, its inclusion into the diet should enhance digestibility and increase propionate production (WANG et al., 2009). 
The extremely acidic $\mathrm{pH}$ obtained during in vitro incubation may interfere with the ruminal microorganism-related processes, inhibiting the action of fibrolytic and methanogenic bacteria and resulting in reduced DM degradation and gas production (VAN KESSEL; RUSSELL, 1996; HINDRICHSEN; KREUZER, 2009; RAMIN; HUHTANEN, 2012).

Citrus pulp produced more methane per gram of incubated DM $(P<0.05)$ than other ingredients. However, when methane production is evaluated based on degraded DM, the corresponding order of ingredients changes in accord with their fiber content. Corn grain and crude glycerin, exhibiting low fibrous carbohydrate contents, produced low amounts of methane $(P<0.05)$ per gram of degraded DM. Pectin, abundant in citrus pulp, might be fermented in the rumen, resulting in a higher proportion of acetic acid (POULSEN et al., 2012) that provides more $\mathrm{H}_{2}$ and $\mathrm{CO}_{2}$ and thus favors methane production. However, corn grain and crude glycerin enable propionate production due to their high starch and glycerol contents (WANG et al., 2009).

Citrus pulp and corn grain showed the highest $\mathrm{CO}_{2}$ production based on ingredient degradation $(P<0.05)$; however, when the above values were expressed per gram of degraded feed, only the citrus pulp showed the highest $\mathrm{CO}_{2}$ production value.
Fiber-rich ingredients, i.e., soy hulls, corn silage, and citrus pulp (Table 1) also exhibited high $\mathrm{CH}_{4}$ production coupled with low $\mathrm{CO}_{2}$ production, when expressed per gram of degraded DM. Thus, the increased activity of methanogenic bacteria is possibly due to the greater availability of $\mathrm{CO}_{2}$ and $\mathrm{H}_{2}$, which are formed during acetate production by the fermentation of fiber.

The end products of ruminal fermentation depend on the diet ingredients, with the acetate:propionate ratio being lower for concentrates (cereals) than for fibrous feeds (forage). Decreased acetate:propionate ratios result in minor $\mathrm{CH}_{4}$ production and possibly enhance the efficiency of feed energy use (WOLIN, 1960; BLAXTER, 1962; PEREIRA et al., 2006).

A negative correlation was detected between DM degradation resulting in $\mathrm{CH}_{4}$ production $\left(\mathrm{mL} \mathrm{g}^{-1} \mathrm{DM}\right.$ incubated, $R^{2}=-0.25 ; P<0.05 ; \mathrm{mL} \mathrm{g}^{-1} \mathrm{DM}$ degraded, $\left.R^{2}=-0.84 ; P<0.0001\right)$ and the final incubation $\mathrm{pH}$ value (Table 2). Occasionally, the higher DM degradation levels of corn grain and crude glycerin led to low final $\mathrm{pH}$ and low $\mathrm{CH}_{4}$ production. The starch-fermenting bacteria of ruminants produce significant quantities of propionate, exhibiting great potential to reduce the mean ruminal $\mathrm{pH}$ due to the formation of lactic acid as an intermediate during the conversion of starch to propionate (SLYTER et al., 1966; HUNGATE, 1966; RUSSELL, 1998).

Table 2. Final $\mathrm{pH}, \mathrm{DM}$ degradation, and $\mathrm{CH}_{4}$ and $\mathrm{CO}_{2}$ production after 24-h in vitro incubation.

\begin{tabular}{|c|c|c|c|c|c|c|}
\hline \multirow{2}{*}{ Ingredient } & \multirow{2}{*}{ final $\mathrm{pH}$} & \multirow{2}{*}{$\begin{array}{c}\text { Deg, } \mathrm{g} \mathrm{kg}^{-1} \\
\text { DM }\end{array}$} & \multicolumn{2}{|c|}{$\mathrm{CH}_{4}$} & \multicolumn{2}{|c|}{$\mathrm{CO}_{2}$} \\
\hline & & & $\mathrm{mL} \mathrm{g}^{-1}$ & $\mathrm{~mL} \mathrm{gd}^{-1}$ & $\mathrm{~mL} \mathrm{~g}^{-1}$ & $\mathrm{~mL} \mathrm{gd}^{-1}$ \\
\hline Citrus pulp & $5.2^{\mathrm{c}}$ & $341^{\circ}$ & $13.5^{\mathrm{a}}$ & $48.0^{\mathrm{a}}$ & $47.1^{\mathrm{a}}$ & $166.5^{\mathrm{a}}$ \\
\hline Corn grain & $5.1^{d}$ & $571^{\mathrm{b}}$ & $11.3^{\mathrm{b}}$ & $20.5^{b}$ & $43.3^{\mathrm{a}}$ & $85.5^{\mathrm{c}}$ \\
\hline Corn silage & $5.4^{b}$ & $288^{\mathrm{c}}$ & $10.6^{\mathrm{b}}$ & $45.4^{\mathrm{a}}$ & $32.1^{\mathrm{b}}$ & $127.2^{b}$ \\
\hline Soy hulls & $5.5^{\mathrm{a}}$ & $305^{c}$ & $11.9^{b}$ & $45.2^{\mathrm{a}}$ & $32.2^{\mathrm{b}}$ & $127.7^{b}$ \\
\hline Crude glycerin & $4.9^{\mathrm{e}}$ & $792^{a}$ & $11.7^{\mathrm{b}}$ & $16.9^{b}$ & $21.0^{\mathrm{c}}$ & $26.2^{\mathrm{d}}$ \\
\hline $\mathrm{P}$ & $* * *$ & $* * *$ & ns & $*$ & $* * *$ & $*$ \\
\hline SE & 0.02 & 4.8 & 1.5 & 7.1 & 4.5 & 20.6 \\
\hline
\end{tabular}

Means followed by the same letters are not different $(P>0.05)$.

SE: standard error; gd: gram degraded

ns, not significant $(P>0.05) ; *(0.05>P>0.01) ; * * *(P<0.001)$. 


\section{Conclusions}

Corn grain and crude glycerin produce less methane per gram of degraded food. The correlation of methane production with the degradation of ingredients is important for their classification, being a possible tool for formulating diets with a lower methane production potential.

\section{References}

ASSOCIATION OF OFFICIAL ANALYTICAL CHEMISTS - AOAC. Official methods of analysis. Arlington: Association of Official Analytical Chemists, 1984.

BLAXTER, K. L. The energy metabolism of ruminants. Springfield, IL: Thomas, C. C., 1962. 329 p.

BLUMMEL, M.; STEINGAS, H.; BECKER, K. The relationship between in vitro gas production, in vitro microbial biomass yield and $15 \mathrm{~N}$ incorporation and its implications for the prediction of voluntary feed intake of roughages. Britsh Journal of Nutrition, London, v. 77, n. 6, p. 911-921, 1997.

CONE, J. W. The development, use and application of the gas production technique as the DLO Institute for Animal Science and Health (ID-DLO), Lelystad, The Netherlands. In: DEAVILLE, E. R.; OWEN, E.; ADESOGEN, A. T.; RYMER, C.; HUNTINGTON, J. A.; LAWRENCE, T. L. J. (Ed.). In vitro techniques for measuring nutrient supply to ruminants. BSAS, Edinburgh, UK, 1998. p. 65-78. (BSAS Occ. Publ. No. 22).

DONKIN, S. S. Glycerol from biodiesel production: the new corn for dairy cattle. Revista Brasileira de Zootecnia, Viçosa, v. 37, p. 280-286, 2008. Suplemento Especial.

ELLIS, J. L.; KEBREAB, E.; ODONGO, N. E.; McBRIDE, B. W.; OKINE, E. K.; FRANCE, J. Prediction of methane production from dairy and beef cattle. Journal of Dairy Science, Champaign, v. 90, n. 7, p. 3456-3466, 2007.

FERRARO, S. M.; MENDOZA, G. D.; MIRANDA, L. A.; GUTIÉRREZ, C. G. In vitro gas production and ruminal fermentation of glycerol, propylene glycol and molasses. Animal Feed Science and Technology, Amsterdam, v. 154, n. 1-2, p. 112-118, 2009.

GRAINGER, C.; BEAUCHEMIN, K. A. Can enteric methane emissions from ruminants be lowered without lowering their production? Animal Feed Science and Technology, Amsterdam, v. 166-167, p. 308-320, 2011.
HENDRIX, D. L. Rapid extraction and analysis of nonstructural carbohydrates in plant tissues. Crop Science, Madison, v. 33, n. 6, p. 1306-1311, 1993.

HINDRICHSEN, I. K.; KREUZER, M. High methanogenic potential of sucrose compared with starch at high ruminal $\mathrm{pH}$. Journal of Animal Physiology and Animal Nutrition, Berlin, v. 93, n. 1, p. 61-65, 2009.

HUNGATE, R. E. The rumen and its microbes. New York: Academic Press, 1966. 533 p.

JANSSEN, P. H. Influence of hydrogen on rumen methane formation and fermentation balances through microbial growth kinetics and fermentation thermodynamics. Animal Feed Science and Technology, Amsterdam, v. 160, n. 1, p. 1-22, 2010.

LEE, S. Y.; LEE, S. M.; CHO, Y. B.; KAM, D. K.; LEE, S. C.; KIM, C. H.; SEO, S. Glycerol as a feed supplement for ruminants: In vitro fermentation characteristics and methane production. Animal Feed Science and Technology, Amsterdam, v. 166-167, p. 269-274, 2011.

MITSUMORI, M.; SUN, W. Control of rumen microbial fermentation for mitigating methane emissions from the rumen. Journal of Animal Science, Champaing, v. 21, n. 1, p. 144-154, 2008.

PEDREIRA, S. M.; PRIMAVESI, O. Impact of animal production on the environment. In: BERCHIELLI, T. T.; PIRES, A. V.; OLIVEIRA, S. G. (Ed.). Ruminants nutrition. Jaboticabal: Funep, 2006. p. 497-511.

PEREIRA, E. M. O.; EZEQUIEL, J. M. B.; BIAGIOLI, B.; FEITOSA, J. V. Methane and carbon dioxide production in vitro in ruminal liquid from different bovines fed with total mixed ration. Archivos Latinoamericanos de Produccion Animal, Mayagues, v. 14, n. 4, p. 120-127, 2006.

PIRONDINI, M.; MALAGUTTI, L.; COLOMBINI, S.; AMODEO, P.; CROVETTO, G. M. Methane yield from dry and lactating cows diets in the Po Plain (Italy) using an in vitro gas production technique. Italian Journal of Animal Science, Pavia, v. 11, n. 3, p. 330-335, 2012.

POULSEN, M.; JENSEN, B. B.; ENGBERG, R. M. The effect of pectin, corn and wheat starch, inulin and $\mathrm{pH}$ on in vitro production of methane, short chain fatty acids and on the microbial community composition in rumen fluid. Anaerobe, London, v. 18, n. 1, p. 83-90, 2011.

RAMIN, M.; HUHTANEN, P. Development of an in vitro method for determination of methane production kinetics using a fully automated in vitro gas system-A modelling approach. Animal Feed Science and Technology, Amsterdam, v. 174, n. 3-4, p. 190-200, 2012. 
RUSSELL, J. B. The importance of $\mathrm{pH}$ in the regulation of ruminal acetate to propionate ratio and methane production in vitro. Journal of Dairy Science, Champaing, v. 81, n. 12, p. 3222-3230, 1998.

RYMER, C.; HUNTINGTON, J. A.; GIVENS, D. I. Effects of inoculum preparation method and concentration, method of inoculation and pre-soaking the substrate on the gas production profile of high temperature dried grass. Animal Feed Science and Technology, Amsterdam, v. 78, p. 199-213, 1999.

SLYTER, L. L.; BRYANT, M. P.; WOLIN, M. J. Effect of $\mathrm{pH}$ on population and fermentation in a continuously cultured rumen ecosystem. Applied Microbiology, Washington, v. 14, n. 4, p. 573-578, 1966.

TAMBURINI, A.; COLOMBINI, S.; PENALTI, E.; ZUCALI, M.; ROVEDA, P.; RAPETTI, L.; CROVETTO, G. M. Methane emission in livestock and diets characteristics. In: CROVETTO, G. M. (Ed.). Energy and protein metabolism and nutrition: Part 7. Energy/ Protein nutrition and environmental sustainability. 127. Wageningen: Wageningen Academic Publihers, 2010. p. 465-466.

TODD, R. W.; COLE, N. A.; CASEY, K. D.; HAGEVOORT, R.; AUVERMANN, B. W. Methane emissions from southern high plains dairy wastewater lagoons in the summer. Animal Feed Science and Technology, Amsterdam, v. 166-167, 23 June, p. 575580, 2011.
VAN KESSEL, J. S.; RUSSELL, J. B. The effect of pH on ruminal methanogenesis. FEMS Microbiology and Ecology, Amsterdam, v. 20, n. 4, p. 205-210, 1996.

VAN NEVEL, C. J.; DEMEYER, D. I. Feed additives and other interventions for decreasing methane emissions. In: WALLACE, R. J.; CHESSON, A. (Ed). Biotechnology in animal feeds and animal feeding. Weinheim: VCH, 1995. p. 329-349.

VAN SOEST, P. J. Nutritional ecology of the ruminant. 2. ed. London: Comstock Publishing Associates, 1994. $476 \mathrm{p}$.

VAN SOEST, P. J.; ROBERTSON, J. B.; LEWIS, B. A. Methods for dietary fiber, neutral detergent fiber, and nonstarch polysaccharides in relation to animal nutrition. Journal of Dairy Science, Champaing, v. 74, n. 10, p. 3583-3597, 1991.

WANG, C.; LIU, Q.; HUO, W. J.; YANG, W. Z.; DONG, K. H.; HUANG, Y. X.; GUO, G. Effects of glycerol on rumen fermentation, urinary excretion of purine derivatives and feed digestibility in steers. Livestock Science, Amsterdam, v. 121, n. 1, p. 15-20, 2009.

WOLIN, M. J. A theoretical rumen fermentation balance. Journal of Dairy Science, Champaing, v. 40, n. 1452, p. 1452-1459, 1960.

WUEBBLES, D. J.; HAYHOES, K. Atmospheric methane and global change. Earth - Science Review, Amsterdam, v. 57, n. 3-4, p. 177-210, 2002. 
